\title{
Persuasive Systems Design Features in Promoting Medication Management for Consumers
}

\author{
Khin Than Win \\ University of Wollongong \\ win@uow.edu.au
}

\author{
Judy Mullan \\ University of Wollongong \\ jmullan@uow.edu.au \\ Harri Oinas-Kukkonen \\ University of Oulu \\ harri.oinas-kukkonen@oulu.fi
}

\author{
Sarah Howard \\ University of Wollongong \\ sahoward@uow.edu.au
}

\begin{abstract}
Medication safety continues to be a growing concern in the healthcare industry. Providing medication information to consumers and supporting selfmanagement would help to reduce medication errors and to increase medication adherence. This paper reviews the persuasive systems design features used in current medication management applications for consumers. A database search was conducted to identify relevant articles, which were then reviewed using the Persuasive Systems Design model as a framework for analysis. The results highlighted the applicability of these features for the medication management information systems available to consumers. Primary task support and Dialogue support categories were highly cited in the articles. System credibility support category was moderately cited and the Social support category was cited least in the reviewed articles. Tailoring, monitoring and reminder features have been considered more than the other features in previous studies.
\end{abstract}

\section{Introduction}

Medication safety continues to be a growing concern in healthcare industry. Providing consumers with good quality medication information is one of the key factors which will help to reduce medication errors and improve the quality use of medicines. Wellinformed consumers will better understand their medication management needs, which will ultimately promote safe medication self-management [1]. Since non-adherence to prescribed medication limits the success of treatment [2], it is important to ensure that consumers take their medication(s) as prescribed.
Previous studies have indicated that adherence monitoring should be performed routinely to ensure therapeutic efficacy and to avoid unnecessary dose and regimen changes in order to limit health care costs [3, 4].

Advancement in technology has increased the opportunity for healthcare solutions to be delivered online to consumers. There is evidence that supports the contention that online health information provision, education and management support can benefit health consumers[5]. Several medication management applications have been developed to assist consumers with their medication management and monitoring. To date, most of these applications have been developed ad hoc, rather than being systemically developed by taking into consideration the design features of the applications.

The effectiveness of the internet in modifying consumer behaviour has been reported in previous studies [6, 7]. A comprehensive framework, known as the Persuasive Systems Design (PSD) model has been developed to assist with designing and evaluating systems that influence the attitudes or behaviours of users [8]. The PSD model includes [8] (see Appendix 1):

1. Primary Task Support (Reduction, Tunneling, Tailoring, Personalization, Self-monitoring, Simulation, Rehearsal);

2. Dialogue Support (Praise, Rewards, Reminders, Suggestion, Similarity, Liking, Social Role);

3. System Credibility Support (Trustworthiness, Expertise, Surface credibility, Real-world feel, Authority, Third-party endorsements, Verifiability); and 
4. Social Support (Social learning, Social comparison, Normative influence, Social facilitation, Cooperation, Competition, Recognition) [8]

To better understand the current design features of available medication management information systems and the applicability of the PSD model, targeted literature review on persuasive systems design features in consumers' medication management information systems is conducted.

\section{Methods}

\subsection{Literature Search}

A database search was conducted to identify relevant articles by using the following online databases; PubMed, PsycINFO, and Medline. The search was conducted in August 2015 and the search was limited to those published from 2005 through to 2015. A key word search was performed using the following search string: "(medication OR medic*) AND (patient OR care OR carer OR consum* OR pharmacy OR pharmacist) AND (manag* OR remind*) AND (web* OR computer* OR internet* OR online OR mobile OR mHealth OR digital OR technology OR SMS) NOT (electron* OR computeriz* OR record OR hospital OR physician OR CPOE OR EHR OR EMR)”.

2.1.1. Inclusion and Exclusion Criteria. To be considered for inclusion in the review, articles were required to meet the following criteria. Firstly, the article should have been in a peer reviewed academic journal or a peer reviewed paper from an international scientific conference. Secondly, the article must have discussed web-based applications or applications for a smartphone or similar wireless mobile device. Thirdly, the article must have discussed the design features that were used to promote medication management. Articles that focused on behaviours other than medication management, such as smoking cessation, nutritional interventions, or promoting physical activity were excluded from the review. In addition, articles which did not focus on consumers but applications intended to use only by health professionals, were also excluded.

2.1.2. Data Extraction and Coding. Using the inclusion and exclusion criteria outlined above, selected articles were then reviewed using the PSD model as a framework for analysis. The persuasive design features were extracted in four categories: primary task support, dialogue support, system credibility support, and social support. Each of these categories was further divided into seven subcategories. An Excel spreadsheet was prepared with information of the final 13 selected articles for coding purposes. The coding of the full-text articles was initially conducted independently by two of the researchers. Once completed, the researchers selected a representative sample of the text coded according to one or more elements of the PSD model and discussed any discrepancies in coding until consensus was achieved.

Table 1: Reviewed articles

\begin{tabular}{|c|c|c|c|c|}
\hline Article & Study type & $\begin{array}{c}\text { Health } \\
\text { condition }\end{array}$ & $\begin{array}{c}\text { Tech } \\
\text { nolog } \\
\mathrm{y}\end{array}$ & Name \\
\hline 1. [9] & $\begin{array}{c}\text { Non- } \\
\text { randomised } \\
\text { trial }\end{array}$ & $\begin{array}{c}\text { Schizophre } \\
\text { nia }\end{array}$ & App. & FOCUS \\
\hline 2. [10] & $\begin{array}{c}\text { Non- } \\
\text { randomised }\end{array}$ & HIV & Web & $\begin{array}{c}\text { Virtual } \\
\text { intervention }\end{array}$ \\
\hline 3. [11] & $\begin{array}{c}\text { System } \\
\text { development }\end{array}$ & general & Web & $\begin{array}{c}\text { Connection to } \\
\text { health }\end{array}$ \\
\hline 4. [12] & $\begin{array}{l}\text { Design and } \\
\text { development }\end{array}$ & general & App & $\begin{array}{l}\text { Wireless Pill } \\
\text { box }\end{array}$ \\
\hline 5. [13] & $\begin{array}{l}\text { Randomized } \\
\text { controlled }\end{array}$ & $\begin{array}{l}\text { Chronic } \\
\text { disease }\end{array}$ & SMS & $\begin{array}{c}\text { Text message } \\
\text { reminder }\end{array}$ \\
\hline 6. [14] & $\begin{array}{c}\text { System } \\
\text { requirement }\end{array}$ & $\begin{array}{l}\text { Cancer } \\
\text { pain }\end{array}$ & App & $\begin{array}{l}\text { Cancer pain } \\
\text { management }\end{array}$ \\
\hline 7. [15] & $\begin{array}{l}\text { Randomized } \\
\text { controlled }\end{array}$ & \begin{tabular}{|l} 
kidney \\
transplant
\end{tabular} & App & $\begin{array}{c}\text { Electronic } \\
\text { medication } \\
\text { tray }\end{array}$ \\
\hline 8. [16] & $\begin{array}{l}\text { Randomized } \\
\text { controlled }\end{array}$ & $\begin{array}{c}\text { Multiple } \\
\text { medication }\end{array}$ & App & ALICE \\
\hline 9. [17] & $\begin{array}{c}\text { Pilot } \\
\text { evaluation of } \\
\text { system }\end{array}$ & HIV & Web & $\begin{array}{l}\text { Collaborative } \\
\text { awareness } \\
\text { system }\end{array}$ \\
\hline 10. [18] & $\begin{array}{c}\text { Non- } \\
\text { randomised } \\
\text { controlled trial }\end{array}$ & $\begin{array}{c}\text { Chronic } \\
\text { pain }\end{array}$ & Web & $\begin{array}{l}\text { Chronic pain } \\
\text { management }\end{array}$ \\
\hline 11. [19] & $\begin{array}{c}\text { Randomized } \\
\text { controlled }\end{array}$ & Diabetes & Web & $\begin{array}{c}\text { Diabetes Teen } \\
\text { Talk }\end{array}$ \\
\hline 12. [20] & $\begin{array}{c}\text { Initial } \\
\text { feasibility } \\
\text { study }\end{array}$ & HIV & Web & $\begin{array}{c}\text { Youth } \\
\text { Antiretroviral }\end{array}$ \\
\hline 13. [21] & $\begin{array}{l}\text { Medication } \\
\text { scheduler } \\
\text { design }\end{array}$ & \begin{tabular}{|c|} 
Child \\
centered \\
medication
\end{tabular} & $\begin{array}{l}\text { App } \\
\& \\
\text { SMS }\end{array}$ & $\begin{array}{c}\text { MyMediHealt } \\
\text { h }\end{array}$ \\
\hline
\end{tabular}


Table 2: Persuasive system features in available medication management systems for consumers

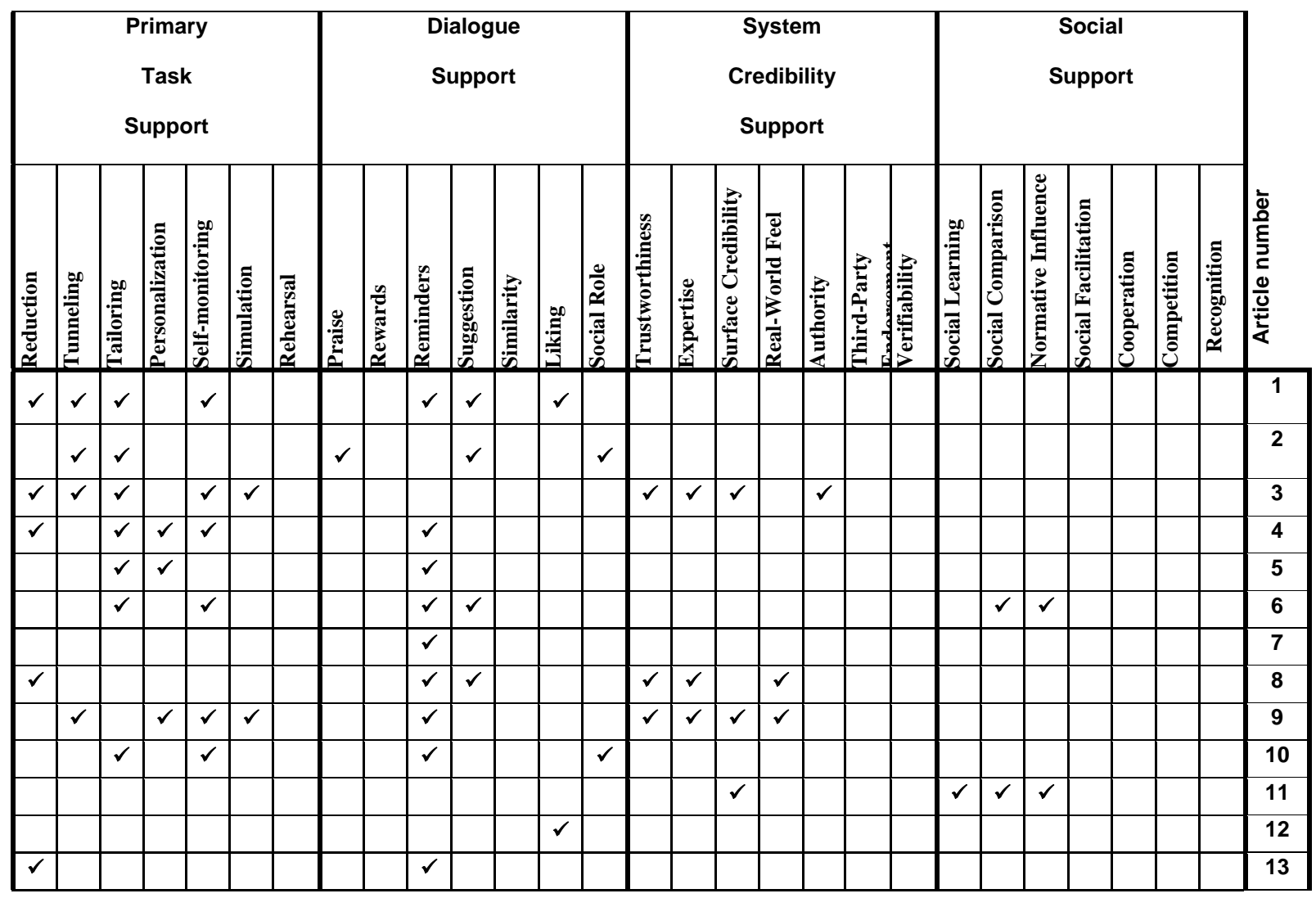

\section{Results}

The initial database search yielded 17658 potentially relevant articles. From this set of articles, 17484 were excluded on the basis that the article title did not meet the inclusion criteria, and 15 duplicates were excluded. Of the remaining 174 articles, a further 109 articles were excluded on the basis that the article abstract did not meet the inclusion criteria. The full text of the remaining 65 articles was assessed and 52 articles were excluded on the basis that the article did not provide sufficient examination of persuasive design features. The resulting 13 articles were included in the review.

\subsection{Primary Task Support}

The primary task support category includes design principles that support the carrying out of the user's primary task [8]. Primary task support features assist the user in achieving the task for which they are using the system, which for the purposes of this review was medication management.

Tailoring was the most cited feature (7 out of 13 articles), followed by self-monitoring in the Primary task support category.

3.1.1. Tailoring. Seven out of 13 articles reviewed included aspects relating to the principle of tailoring [9-14, 18]. Tailoring was implemented based on the medication and questionnaire answers, and feedback. For example, the "FOCUS" system [7] requires that users answer a series of multiple choice questions each day. The system provides tailored messages, based on the responses given by the user, encouraging the user to engage in medication selfmanagement strategies. Furthermore, the system provides tailored intervention self-management content based on user selection [9].

Tailoring occurred in one system[10] via an interactive virtual nurse that provides feedback to the patient based on user input. The feedback is tailored to the patient using an algorithm. For instance, personal information is collected from the patient, 
such as their medication intake, and on the basis of this information recommendations are made via video clips of the virtual nurse [10]. The Connection to Health Patient Self-Management System [11] on the other hand, includes an interactive module that facilitates patient's to select health behavior goals. Based on the user's input, the system provides a tailored action plan to help the patient identify and overcome barriers to success [11].

The wireless pillbox medication self-management system [12] provides medication taking reminders, but only when the patient has forgotten to take their medication [12]. In another study, tailored messages based on the medication and frequency of medication use were sent to patients via their mobile phone[13].

A cancer pain management application [14] provided tailored patient recommendations based on their own preferences. For example, the application might recommend the patient listen to music, if they have selected this as a pain management strategy [14]. On the other hand a chronic pain management application [18] uses demographic patient information and their medical conditions to tailor an action plan for their medication management [18].

3.1.2. Reduction. Five out of 13 articles in the review included some aspects relating to the principle of reduction $[9,11,12,16,21]$. The reduction feature was presented for easy navigation, user friendliness, reduced complexity, identification and easy accessibility in the reviewed articles. The selfmanagement system "FOCUS"[9] implements the principle of reduction in order to be more userfriendly for people with schizophrenia [9]. In this particular application, the number of steps required to access content is minimized and memory aids such as a visible 'continue' button is used to facilitate navigation. Furthermore, a simple screen layout and language is used to reduce complexity of the user experience. Glasgow et al. indicated in their article that The Connection to Health action plan [11] implements multimedia modules that guide the user through a planning process for modification of a number of health behaviors, including medication management [11]. These multimedia modules reduce the complexity of the planning process by facilitating patient goal setting behaviors and providing relevant supporting strategies. In addition, to reduce the number of steps required for the patient to maintain a record of medication use, a pill box was implemented using automatic wireless sensors to detect the opening and closing of the patient's pill box [12]. The sensor data was used to determine whether or not the patient had taken their medication, thus eliminating the need for the patient to self-monitor medication usage.

Three of the systems used reduction by providing images of medication and medication packaging to the patient as part of their applications [12, 16, 21]. This allows the patient to identify the required medication without needing to read the label. One of these systems provides the image in a reminder message, another provided a text message that included a URL that linked to a webpage with an image of the medication [21].

3.1.3. Tunneling. Four out of 13 reviewed articles presented the principle of tunneling by providing necessary actions [9-11, 17]. The "FOCUS" system[9] used tunneling in the form of daily prompts for the user to answer multiple-choice questions. The answers to these questions resulted in the system guiding user to engage in selfmanagement strategies [9]. The system which uses an interactive virtual nurse to guide the user through the learning process of taking their prescribed medicine[10], relies on the user's responses to the interactive process to guide the patient towards the target behavior [10]. The Connection to Health system [11] provides tunneling as a series of multimedia modules that guide the user through the steps of planning their health behaviour changes [11]. A collaborative awareness system for chronic disease medication adherence, used data collected from the patient to trigger the dispatching of messages, which provide useful advice to guide the patient [17].

3.1.4. Personalization. The principle of personalization feature is seen in three out of the13 articles reviewed [12, 13, 16, 17]. One system displayed personalized information which included medication history, current prescriptions, medicationtaking records, adherence rate and a record of the patient's condition [12]. In another study, reminder messages were sent to participants via their mobile phone. Information specific to the individual was included in the messages, such as appointment times and dates [13]. The ALICE application allows the user to input personal information, which is subsequently used by the system to provide tailored content for the patient [16]. Importantly however, the applications do not provide any personalized content to the user, and therefore doesn't satisfy the requirements of personalization. The collaborative awareness application provided visualization of user performance as graphs. Personalized information such as medication adherence performance or estimated plasma concentration was available to the patient [17]. 
3.1.5. Self-monitoring. In the articles reviewed, six of the 13 include some aspect that is related to the principle of self-monitoring [9, 11, 12, 14, 17, 18]. The FOCUS system [9] prompts the user to engage in a brief self-assessment each day. This system presents multi-choice response options to questions presented to the user regarding their status in their target domains [9]. The Connection to Health Patient Self-Management System [11] requires the patient to develop an action plan by selecting goals for health behaviors. This system also provides ongoing access to the plan for continued selfmonitoring by the patient [11]. For the wireless pillbox system [12], self-monitoring was provided automatically in a medication monitoring system that incorporated an electronic pill-box. Wireless sensors monitored the opening and closing of the pill box [12]. The cancer pain management application uses self-monitoring to allow the patient to self-assess and log their pain levels over time based on their pain medication intake [14]. The collaborative awareness system [17] which promotes self-monitored medication adherence for HIV patients, allows patients to self-report adherence and keep an updated record of their performance [17]. The chronic pain management program[18] incorporates a questionnaire about demographics, medical and psychological conditions, pain, general well-being, and daily functioning, used as a base line measure for self-monitoring and self-reporting health outcomes [18].

3.1.6. Simulation. In the articles reviewed, two out of the 13 included some aspect that is related to the principle of simulation $[11,17]$. The Connection to Health system[11] includes modules that guide the patient through an action planning process and provides simulation of outcomes. This system allows the user to self-select goals for health behavior change and provides them with relevant benefits, barriers to success, and strategies. The HIV medication management application [17] on the other hand, provides a personalized simulation based on the patient's data. The simulation represents a drop of the patient's blood, and displays to the patient a visualization of their cell count and viral load.

\subsection{Dialogue Support}

The dialogue support category includes design principles that support human-computer interactions in a way that users would consider to be social or interpersonal interactions. These interactions incorporate feedback to the user in the form of dialogue, such as prompts, suggestions and reminders.

3.2.1. Praise. In the articles reviewed, one out of 13 articles included aspects that related to the principle of praise [10]. This praise principle was only evident in the application which used 'virtual nurse' who provided vocal assistance to the patient, including positive reinforcement [10].

3.2.2. Reminders. Nine of the 13 articles reviewed, included aspects that related to the principle of reminders [9, 12-18, 21]. Reminders were included as: auditory signals and visual notifications to prompt daily self-assessment task $[9,16]$ medication reminders when patients have forgotten [12, 15]; as well as SMS's for medication dosage and times [13]. In some cases, the program only provided reminders while the patient was using the system and the MyMediHealth medication management system [21] sent text message reminders to patients containing a webpage link to record if the medication was taken [21].

3.2.3. Suggestion. In the 13 articles reviewed, four included aspects relating to the principle of suggestion [9, 10, 14, 16]. The FOCUS system [9] provided suggestions to the patient as the 'Quick Tips' function [9]. As part of this application, patients receive a brief text suggestion, either by pressing the 'Quick tips' icon or in response to feedback given by the patient. In the virtual intervention study tailored suggestions, based on feedback, were provided to the patient by the virtual nurse guiding them through the medication taking process [10]. In contrast, the cancer pain management system provided suggestions based on the patient data for different pain management techniques [14], and the ALICE application provided suggestions and advised patients on how to take and store their medications [16].

3.2.4. Liking. Two of the 13 articles reviewed, included aspects that related to the principle of liking $[9,20]$. The FOCUS application used imagery to engage the user, such as cartoons and messages that visually simulate hand written notes [9]. Whereas, the HIV application (ref) in an attempt to appeal to young people with HIV included interactions with an animated character mimicking conversational interpersonal interactions [20].

3.2.5. Social Role. In the articles reviewed, two of the 13 articles included aspects that related to the principle of social role $[10,18]$. The virtual nurse 
intervention in the HIV application, performed a social role by providing feedback and reinforcement to the patient [10]. While, the digital coaching in the pain management program emulates an interaction with a real pain management expert and delivers this 'social role' by using text, images and videos.

\subsection{System Credibility Support}

System credibility support abides by the principle whereby the persuasive capability of a system can be improved by incorporating features that indicate to the user that the system is credible.

3.3.1. Trustworthiness. In the 13 articles reviewed, three included aspects relating to the principle of trustworthiness [11, 16, 17]. The Connection to Health provides a welcome message to the user that includes a message from the patient's practitioner indicating that the program is part of their care plan. The ALICE application provides images of each medication and its packaging and the Collaborative awareness system for HIV patients provides graphs and simulations of patient health data in real-time, all of which may be perceived as trustworthy by the patients.

3.3.2. Expertise. In the articles reviewed, three of the 13 articles included aspects that related to the principle of expertise $[11,16,17]$. The Connection to Health system (ref) demonstrates expertise in the principle of trustworthiness by providing a welcome message from the practice [11]. This message suggests that the clinician is involved in the application and is sharing his expertise with the user. The ALICE indicates expertise by providing a complete list of doctors and caregivers associated with each prescription managed by the patient. Whereas, to demonstrate expertise. the collaborative awareness system provides a function for the clinician to send video messages to the patients [17], thereby improving the persuasiveness of the system by including expert advice.

3.3.3. Surface Credibility. In the articles reviewed, three included aspects that related to the principle of surface credibility $[11,17,19]$. Many of the qualities that create surface credibility are not features, but rather the absence of features that would reduce credibility, such as advertisements [8].The Connection to Health system provides well designed and engaging multimedia modules that appear credible, and support this with video messages from the medical practice to further lend credibility [11].
The collaborative awareness system [17] include features that provide evidence of credibility such as graphs and visualization of data that give the impression of scientific credibility, and the Diabetes Teen Talk website provide regular date-stamped message posts lending credibility to a system by demonstrating that the system has currency.

3.3.4. Real World Feel. Two of the 13 articles reviewed included aspects that related to the principle of real-world feel $[16,17]$. The ALICE application provides a list of all the caregivers involved with the patient's medication prescriptions. Whereas, the collaborative awareness system (ref) allows clinicians to send video messages directly to the patients [17].

3.3.5. Authority. In the articles reviewed, one out of 13 articles included aspects that related to the principle of authority [11]. The Connection to Health system uses authority when it includes a welcome message from the clinic [11]. The message makes reference to the clinician that is providing care to the patient.

\subsection{Social Support}

Social support is the persuasive design principle that can be used to motivate users.

3.4.1. Social Learning. In the 13 articles reviewed, one included aspects that related to the principle of social learning [19]. The Diabetes Teen Talk system (19) encourages patients to participate in discussion forums, chat rooms and blogs, all of which facilitate social support and learning.

3.4.2. Social Comparison. In the articles reviewed, two of the 13 articles included aspects relating to the principle of social comparison [14, 19]. The cancer pain management application included features that allow patients to connect through the system to other patients. Similarly, Diabetes Teen Talk includes social comparison by way of introducing users to forums and blogs [19].

3.4.3. Normative Influence. Two of the 13 articles reviewed, included aspects that related to the principle of normative influence [14, 19]. Both the Diabetes Teen Talk [19] and the cancer pain management application [14] implement normative influence by allowing users to communicate through discussion forums, chat rooms and/or blogs.

Overall, PSD features to assist consumers with medication self-management have been identified in 
the 13 reviewed articles. Some of the articles reviewed in this study identified PSD features, but they are still in the phase of analysing the system requirements [14] or in the designed stage [9, 11]. The effectiveness and outcomes of these studies need to be further investigated in the future. However, usability, effectiveness and improved medication adherence have also been reported in the some of the articles reviewed [10, 12, 13, 15-17] and that reinforces the support of PSD features in consumer behaviour change perspectives. It was also reported in the studies that computer-based intervention motivated the participants to be more involved in their health management and the aware of their disease [20].

\section{Discussion and Conclusion}

Persuasive features in medication management information for consumers could be seen in the articles reviewed. This study identifies PSD model applied in practice by reviewing features present in randomised/non-randomised controlled trial, feasibility studies, design and development. Although not all features are presented in the articles reviewed, the results highlighted the applicability of these features in the medication management information systems for consumers. That poses the question, whether those features not seen are not applicable for medication management for consumers or the applications have not considered these features as applications were developed ad hoc without applying on theoretical framework. Oinas-Kukkonen and Harjumaa also noted in their article that systems do not necessarily need to include all PSD features in the application [8]. However, one cannot argue that all features presented were relevant to medication management information provision to consumers. Tailoring, self-monitoring and reminder features are the most cited features for medication management applications reviewed. These features support the consumer self-management for medication and would promote medication adherence.

Important aspects in behavior change interventions such as goal setting and selfmanagement [22] have been seen in the primary task support category of reviewed articles. Goal setting have been provided in The Connection to Health Patient Self-Management System and self-monitoring features could be seen in several systems $[9,11,12$, $14,17,18]$.

Apart from the social support category, most features in other categories have been applied in the medication management application. Possibility of social support features not included in these applications could be that medication information is considered as sensitive information. Privacy and confidentiality are the important aspects for health information [23]. However, having consumer selfmanagement support is important in medication management and having social support features in the system would assist caregivers, family and friends of elderly be involved in their medication management.

With the advancement of social media, motivating users have been conducted through these media. Social support feature probably has not been covered in the reviewed articles as the sensitivity of the health information sharing. It is in contrast to, some of the applications, having more social support features such as physical activity applications[24] and application targeted for smoking intervention [25] .

Rehearsal feature in primary task support category is not seen in the medication management systems reviewed. Although this feature was seen in some of the well being applications as presented in [26], breathing exercise supported by application. This feature has not been applicable in the medication management studies reviewed.

It could also be that the emphases of disease focus on the reviewed articles are different from each other, HIV (Human Immunodeficiency Virus), kidney failure, diabetes, pain management etc. Further study is needed to explore more on disease specific or medication specific features for PSD. Although the initial search revealed high numbers of articles, there are not many articles on medication management information system for consumers. Most studies emphasised on medication management in hospitals, healthcare organisations and health professional perspectives and there are very few articles on consumer self-management of medication. Although the search period is for past 10 years, most of the reviewed articles were from those published in the past 5 years. It could be due to the emphasis of patient centered healthcare in recent years, more research in consumer involvement in their healthcare, advancement in information technology and applications in healthcare.

\section{Acknowledgement}

Authors would like to thank John Matthews for his assistance in undertaking the initial stages of this research study.

\section{References}


[1] K. T. Win, "Implementing patient accessible health information site for diabetes management," in Pacific Asia Conference on Information Systems, 2010, pp. 1790-1797.

[2] A. Lopez Vina, "[Attitude changes needed to foster treatment adherence in patients with asthma]," Arch Bronconeumol, vol. 41, pp. 33440, Jun 2005.

[3] S. Garfield, S. Clifford, L. Eliasson, N. Barber, and A. Willson, "Suitability of measures of selfreported medication adherence for routine clinical use: A systematic review," BMC Medical Research Methodology, vol. 11, 2011.

[4] S. N. Weingart, E. Brown, P. B. Bach, K. Eng, S. A. Johnson, T. M. Kuzel, et al., "NCCN Task Force Report: Oral chemotherapy," JNCCN Journal of the National Comprehensive Cancer Network, vol. 6, 2008.

[5] K. T. Win, N. Hassan, A. Bonney, and D. Iverson, "Benefits of Online Health Education: Perception from Consumers and Health Professionals," Journal of Medical Systems, vol. 39, pp. 1-8, 2015/02/11 2015.

[6] B. J. Fogg, "Persuasive technology: using computers to change what we think and do. 2003," ed: Morgan Kaufmann, 2003.

[7] S. M. Kelders, R. N. Kok, H. C. Ossebaard, and J. E. W. C. Van Gemert-Pijnen, "Persuasive system design does matter: a systematic review of adherence to web-based interventions," Journal of medical Internet research, vol. 14, 2012.

[8] H. Oinas-Kukkonen and M. Harjumaa, "Persuasive systems design: Key issues, process model, and system features," Communications of the Association for Information Systems, vol. 24, p. 28, 2009.

[9] D. Ben Zeev, S. M. Kaiser, C. J. Brenner, M. Begale, J. Duffecy, and D. C. Mohr, "Development and usability testing of FOCUS: A smartphone system for self-management of schizophrenia," Psychiatric Rehabilitation Journal, vol. 36, pp. 289-296, 2013.

[10] J. Cote, G. Rouleau, G. Godin, P. Ramirez Garcia, Y.-G. Gueheneuc, G. Nahas, et al., "Acceptability and feasibility of a virtual intervention to help people living with HIV manage their daily therapies," Journal of Telemedicine and Telecare, vol. 18, pp. 409-212, 2012.

[11] R. E. Glasgow, P. Dickinson, L. Fisher, S. Christiansen, D. J. Toobert, B. G. Bender, et al., "Use of RE-AIM to develop a multi-media facilitation tool for the patient-centered medical home," Implementation Science, vol. 6, pp. 118128, 2011.

[12] M. Hayakawa, Y. Uchimura, K. Omae, K. Waki, H. Fujita, and K. Ohe, "A Smartphone-based Medication Self-management System with Realtime Medication Monitoring," Applied Clinical Informatics, vol. 4, 2013.
[13] H.-L. Huang, Y.-C. J. Li, Y.-C. Chou, Y.-W. Hsieh, F. Kuo, W.-C. Tsai, et al., "Effects of and satisfaction with short message service reminders for patient medication adherence: a randomized controlled study," Biomed Central Medical Informatics \& Decision Making, vol. 13, 2013.

[14] L. A. Jibb, B. J. Stevens, P. C. Nathan, E. Seto, J. A. Cafazzo, and J. N. Stinson, "A SmartphoneBased Pain Management App for Adolescents With Cancer: Establishing System Requirements and a Pain Care Algorithm Based on Literature Review, Interviews, and Consensus," JMIR Research Protocols, vol. 3, 2014.

[15] J. W. McGillicuddy, M. J. Gregoski, A. K. Weiland, R. A. Rock, B. M. Brunner Jackson, S. K. Patel, et al., "Mobile Health Medication Adherence and Blood Pressure Control in Renal Transplant Recipients: A Proof-of-Concept Randomized Controlled Trial," JMIR Research Protocols, vol. 2, 2013.

[16] J. J. Mira, I. Navarro, F. Botella, F. Borrás, R Nuño Solinís, D. Orozco, et al., "A Spanish Pillbox App for Elderly Patients Taking Multiple Medications: Randomized Controlled Trial," Journal of Medical Internet Research, vol. 16, 2014.

[17] J. O. Moore, H. Hardy, P. R. Skolnik, and F. H. Moss, "A collaborative awareness system for chronic disease medication adherence applied to HIV infection," presented at the Annual International Conference of the IEEE Engineering in Medicine \& Biology Society, 2011.

[18] D. C. Nevedal, C. Wang, L. Oberleitner, S. Schwartz, and A. M. Williams, "Effects of an Individually Tailored Web-Based Chronic Pain Management Program on Pain Severity, Psychological Health, and Functioning," Journal of Medical Internet Research, vol. 15, 2013.

[19] K. T. Newton and A. Ashley, "Pilot study of a web-based intervention for adolescents with type 1 diabetes," Journal of Telemedicine and Telecare, vol. 19, pp. 443-449, 2013.

[20] A. Y. Outlaw, S. Naar King, M. Tanney, M. E. Belzer, A. Aagenes, J. T. Parsons, et al., "The initial feasibility of a computer-based motivational intervention for adherence for youth newly recommended to start antiretroviral treatment," AIDS Care, vol. 26, pp. 130-135, 2014.

[21] J. M. Slagle, J. S. Gordon, C. E. Harris, C. L. Davison, D. K. Culpepper, P. Scott, et al., "MyMediHealth - designing a next generation system for child-centered medication management," Journal of Biomedical Informatics, vol. 45, pp. S27-S31, 2010.

[22] S. Michie, C. E. Wood, M. Johnston, C. Abraham, J. J. Francis, and W. Hardeman, "Behaviour change techniques: The development and evaluation of a taxonomic method for reporting and describing behaviour change 
interventions (a suite of five studies involving consensus methods, randomised controlled trials and analysis of qualitative data)," Health Technology Assessment, vol. 19, pp. 1-187, 2015.

[23] A. Ramaprasad, T. Syn, and W. Khin Than, "The Bright, Light, and Blind/Blank Spots in HIPAA Research: An Ontological Analysis," in System Sciences (HICSS), 2015 48th Hawaii International Conference on, 2015, pp. 30233032.

[24] J. Matthews, K. T. Win, H. Oinas-Kukkonen, and M. Freeman, "Persuasive Technology in Mobile Applications Promoting Physical Activity: a Systematic Review," Journal of Medical Systems, vol. 40, pp. 1-13, 2016.

[25] T. Lehto and H. Oinas-Kukkonen, "Persuasive features in web-based alcohol and smoking interventions: a systematic review of the literature," J Med Internet Res, vol. 13, p. e46, 2011.

[26] S. Langrial, T. Lehto, H. Oinas-Kukkonen, M. Harjumaa, and P. Karppinen, "Native mobile applications for personal wellbeing: A persuasive systems design evaluation," in Proceedings Pacific Asia Conference on Information Systems, PACIS 2012, 2012. 
Appendix

Table A1: Persuasive Systems Design Features [8]

\begin{tabular}{|c|c|c|}
\hline $\begin{array}{l}\text { Cat } \\
\text { egor } \\
y\end{array}$ & $\begin{array}{l}\text { Persuasiv } \\
\text { e feature }\end{array}$ & Definition \\
\hline \multirow{7}{*}{$\begin{array}{l}\text { Pri } \\
\text { mar } \\
\mathrm{y} \\
\text { Tas } \\
\mathrm{k} \\
\text { Sup } \\
\text { port }\end{array}$} & $\begin{array}{l}\text { Reductio } \\
\mathrm{n}\end{array}$ & $\begin{array}{l}\text { System should reduce steps users take } \\
\text { when performing target behaviour }\end{array}$ \\
\hline & $\begin{array}{l}\text { Tunnelin } \\
\text { g }\end{array}$ & 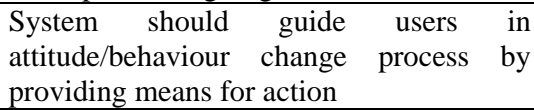 \\
\hline & Tailoring & $\begin{array}{l}\text { System should provide tailored info for } \\
\text { user groups }\end{array}$ \\
\hline & $\begin{array}{l}\text { Personali } \\
\text { zation }\end{array}$ & $\begin{array}{l}\text { System should offer personalized content } \\
\text { and services for individual users }\end{array}$ \\
\hline & $\begin{array}{l}\text { Self- } \\
\text { monitorin } \\
\text { g }\end{array}$ & $\begin{array}{l}\text { System should provide means for users to } \\
\text { track their performance or status }\end{array}$ \\
\hline & $\begin{array}{l}\text { Simulatio } \\
\mathrm{n}\end{array}$ & $\begin{array}{l}\text { System should provide means for } \\
\text { observing link between cause \& effect } \\
\text { with regard to users' behaviour }\end{array}$ \\
\hline & Rehearsal & $\begin{array}{l}\text { System should provide means for } \\
\text { rehearsing target behaviour }\end{array}$ \\
\hline \multirow{7}{*}{$\begin{array}{l}\text { Dial } \\
\text { ogu } \\
\mathrm{e} \\
\text { Sup } \\
\text { port }\end{array}$} & Praise & $\begin{array}{l}\text { System should use praise to provide user } \\
\text { feedback based on behaviours }\end{array}$ \\
\hline & Rewards & $\begin{array}{l}\text { System should provide virtual rewards for } \\
\text { users to give credit for performing target } \\
\text { behaviour }\end{array}$ \\
\hline & $\begin{array}{l}\text { Reminder } \\
\mathrm{s}\end{array}$ & $\begin{array}{l}\text { System should remind users of their target } \\
\text { behaviour while using the system }\end{array}$ \\
\hline & $\begin{array}{l}\text { Suggesti } \\
\text { on }\end{array}$ & $\begin{array}{l}\text { System should suggest users carry out } \\
\text { behaviours while using the system }\end{array}$ \\
\hline & $\begin{array}{l}\text { Similarit } \\
\mathrm{y}\end{array}$ & $\begin{array}{l}\text { System should imitate its users in some } \\
\text { specific way }\end{array}$ \\
\hline & Liking & $\begin{array}{l}\text { System should have a look \& feel that } \\
\text { appeals to users }\end{array}$ \\
\hline & Social & System should adopt a social role \\
\hline \multirow{7}{*}{$\begin{array}{l}\text { Syst } \\
\text { em } \\
\text { Cre } \\
\text { dibil } \\
\text { ity } \\
\text { Sup } \\
\text { port }\end{array}$} & $\begin{array}{l}\text { Trustwort } \\
\text { hiness }\end{array}$ & $\begin{array}{l}\text { System should provide info that is } \\
\text { truthful, fair \& unbiased }\end{array}$ \\
\hline & Expertise & $\begin{array}{l}\text { System should provide info showing } \\
\text { knowledge, experience \& competence }\end{array}$ \\
\hline & $\begin{array}{l}\text { Surface } \\
\text { Credibilit } \\
\mathrm{y}\end{array}$ & $\begin{array}{l}\text { System should have competent and } \\
\text { truthful look \& feel }\end{array}$ \\
\hline & $\begin{array}{l}\text { Real- } \\
\text { World } \\
\text { Feel } \\
\end{array}$ & $\begin{array}{l}\text { System should provide info of the } \\
\text { organization/actual people behind it } \\
\text { content \& services }\end{array}$ \\
\hline & Authority & $\begin{array}{l}\text { System should refer to people in the role } \\
\text { of authority }\end{array}$ \\
\hline & $\begin{array}{l}\text { 3rd-Party } \\
\text { Endorsed }\end{array}$ & $\begin{array}{l}\text { System should provide endorsements from } \\
\text { external sources }\end{array}$ \\
\hline & $\begin{array}{l}\text { Verifiabil } \\
\text { ity }\end{array}$ & $\begin{array}{l}\text { System should provide means to verify } \\
\text { accuracy of site content via outside } \\
\text { sources }\end{array}$ \\
\hline \multirow{3}{*}{$\begin{array}{l}\text { Soci } \\
\text { al } \\
\text { Sup } \\
\text { port }\end{array}$} & $\begin{array}{l}\text { Social } \\
\text { Learning }\end{array}$ & $\begin{array}{l}\text { System should provide means to observe } \\
\text { others performing their target behaviours }\end{array}$ \\
\hline & $\begin{array}{l}\text { Social } \\
\text { Comparis } \\
\text { on }\end{array}$ & $\begin{array}{l}\begin{array}{l}\text { System should provide means for } \\
\text { comparing performance } \\
\text { performance of others }\end{array} \\
\text { with the } \\
\end{array}$ \\
\hline & Normativ & System should provide means for \\
\hline
\end{tabular}

\begin{tabular}{|l|l|l|}
\hline $\begin{array}{l}\text { e } \\
\text { Influence }\end{array}$ & $\begin{array}{l}\text { gathering people who have same goal \& } \\
\text { make them feel norms }\end{array}$ \\
\hline $\begin{array}{l}\text { Social } \\
\text { Facilitati } \\
\text { on }\end{array}$ & $\begin{array}{l}\text { System should provide means for } \\
\text { discerning others who are performing the } \\
\text { behaviour }\end{array}$ \\
\hline $\begin{array}{l}\text { Cooperati } \\
\text { on }\end{array}$ & $\begin{array}{l}\text { System should provide means for co- } \\
\text { operation }\end{array}$ \\
\hline $\begin{array}{l}\text { Competit } \\
\text { ion }\end{array}$ & $\begin{array}{l}\text { System should provide means for } \\
\text { competing with others }\end{array}$ \\
\hline $\begin{array}{l}\text { Recogniti } \\
\text { on }\end{array}$ & $\begin{array}{l}\text { System should provide public recognition } \\
\text { for users who perform their target } \\
\text { behaviour }\end{array}$ \\
\hline
\end{tabular}

